\title{
Comparing the Learning Culture of High and Low Performing High Schools in Pakistan
}

\author{
Muhammad Akram ${ }^{1}$, Karen E. Watkins ${ }^{2}$, Sajid Ahmad Sajid ${ }^{3}$ \\ University of Georgia ${ }^{1,2}$, District Education Office, Lahore ${ }^{3}$
}

\begin{abstract}
The purpose of this study was to compare the learning culture of high and low performing boys and girls high schools in Pakistan. Data collection was accomplished using a translated and adapted version of the Dimensions of a Learning Organization Questionnaire [26], [27]. Data were collected in 164 public boys and girls high schools in Pakistan. The overall results of each school in the Lahore Board exams were also collected from schools. Boys and girls high schools differed significantly on all domains of the learning culture. Statistically significant differences were also found between high and low performing schools on the dimensions of Strategic Leadership and Knowledge Performance. However, neither high and low performing high schools for boys nor for girls showed significant differences on DLOQ dimensions within their gender. Student achievement was significantly correlated to the dimensions of Strategic Leadership for Learning and Knowledge Performance.
\end{abstract}

\section{Introduction}

The concept of a learning organization has received increasing attention in the field of organizational studies [2]. Organizations often expect that learning and knowledge creation take place continuously for individuals and that they will share what they know in ways that promote learning in groups and throughout the organization [26]. Organizations such as schools strive for developing environment conducive to their employees where they can exert their best efforts to demonstrate their efficiency and effectiveness. Schools provide teachers with a suitable workplace, facilities, and a culture in which they are expected to demonstrate best practices in teaching and helping students increase achievement. The idea of a learning culture stresses that to accomplish this, teachers and schools must learn and change rapidly and continuously.

School leaders today are transforming their schools in order to help students develop 21st century skills. They use a variety of strategies to make their schools a learning organization. They transform their schools into vibrant learning communities, engaged in whole system learning, in which teachers and leaders work together and learn together, often with their students, to support learning and development. They intend to create opportunities for continuous learning, promoting dialogue and inquiry, and encourage team learning [26]. They empower teachers through strategic leadership and learning strategies that help teachers improve the culture of their schools. These whole system strategies are deemed essential since they are assumed to improve teacher's effectiveness which, ultimately, helps students increase their achievement.

This paper reports the findings from a survey of an organization's learning culture conducted in Pakistani public schools. Watkins and Marsick [27], [29] developed a diagnostic tool to measure changes in organizational learning practices and cultures based on their model, the Dimensions of the Learning Organization Questionnaire (DLOQ). The DLOQ has been tested and modified through numerous research studies across multiple languages, contexts, and cultures [27]. Yet few researchers employed the DLOQ in a school context. The current study employed in a school context provides a different and important perspective. The researchers adapted the DLOQ for a public school context to investigate differences between boys and girls public high schools' learning culture in Pakistan.

\section{Theoretical Framework}

The model of the learning organization used in this study was that developed by Watkins and Marsick [29]. A learning organization is one in which all systems are aligned to promote learning and change [27]. Figure 1 depicts this model. Over the past seventeen years, this model has been used by many researchers, with over 70 published studies across numerous cultures and contexts. The scales have consistently proven reliable with alpha levels as high as .70 [12] and .80 [4].

Yang, Watkins, and Marsick [2] analyzed data from various studies using structural equation modeling and found that individual and group level learning activities had indirect but significant effects on organizational outcomes. These individual and group learning variables were highly intercorrelated. Others also found high correlations among these dimensions as well as with the performance variables included in the $D L O Q$ : knowledge and financial performance [27]. These studies found that the dimensions of a learning organization explained much of the total variance in the two organizational 
outcome variables-knowledge and financial performance.

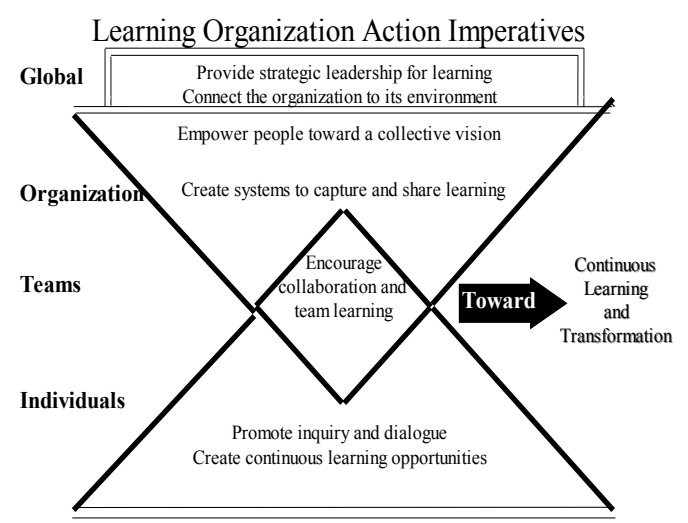

Figure 1. Theoretical framework

Creating continuous learning opportunities is the first of seven dimensions of Watkins and Marsick's learning organization model [29]. This dimension, categorized within the individual level of learning, is the basis for all other dimensions in a learning organization because as individuals learn and grow, so in turn, does the organization. Learning organizations provide steady opportunities to learn, work, and develop strategically to improve how the organization itself responds to challenges. Learning communities in organizations modify their thinking by moving from viewing oneself as separate from the world to seeing the connections between oneself and the world. As a result, individuals, teams, and the entire organization can learn, construct meaning, and transform on a continuous basis [5], [6].

The second dimension of the learning organization model-promoting inquiry and dialogue - is also categorized within the individual level of learning. This dimension encourages the organization to create and promote an environment of experimentation using questioning techniques as a means for providing feedback [7], [16], [28]. Continuous improvement is achieved by seeking feedback, using interpersonal relationships, positive, respectful communication, and proactive problem solving [7]. Inquiry allows for creative or generative thinking and learning. It permits the possibility of finding new solutions for an improved organizational system.

Team learning - the third dimension - asks team members to effectively influence the work of other individuals within the team and members of other teams within the organization. In this manner, continuous learning systems and positive transformations take place throughout the organization [20], [25]. Teams or groups are the bridge between the organization and the individual, enabling the broader vision of the organization to be communicated and understood in terms of what each individual must do to enact that vision. Healthy teams question current practices and prevailing wisdom to generate new approaches to nagging problems [26].

At the organizational level, embedded learning takes place. In embedded systems, people take initiative, give people choices in their work, and share learning and best practices across the organization. In an ideal learning organization, problems and mistakes are viewed as learning opportunities and every member of the organization is involved in networks of relationships that provide support for continuous learning and problem solving [8], [11]. Sustaining the learning organization by capturing and sharing learning requires a focus on system level learning, working collaboratively for the sake of learning and developing accountability models to fuel continuous improvement [22].

Empowerment - the fifth dimension-has proven elusive both as a theoretical and an empirical construct [9]. Empowerment may increase teachers' job satisfaction and even their commitment and sense of collegiality, but there is no guarantee that instructional practice will change, pedagogical quality will improve, or student performance will benefit [9].

System Connections - the sixth dimension-is another significant part of a learning culture. Employees, in connected systems, are provided support to balance their work and family. Thinking from a global perspective, systems allow their employees to bring customers' views into the problem solving and decision-making process and require organizations to consider the impact of decisions on employees' morale [29].

Leadership is one of the most significant dimensions of a learning culture. Leadership within the school setting can no longer be left to one individual. In order to improve the effectiveness of schools, administrative leaders need to establish leadership teams that work collaboratively to implement the complex demands and roles associated with school reform [13], [14], [24]. Chrispeels et al. [13] found that as teacher team members and principals engage through dialogue, collaborative work, and shared experiences, they develop shared mental models and strong leadership skills. Chrispeels et al. [13] referred to these groups as shared leadership teams and through their study discovered that these teams provide a communication link between the principal and other colleagues. Sharing the pedagogical knowledge increased and the change in teaching practices developed as well [13].

\section{Related DLOQ Research}

Combining the dimensions of the $D L O Q$ with research on school improvement provides evidence 
of the direct or indirect impact of these dimensions on organizational and individual performance. Imran, Rizvi, and Ali [18], for example, conducted a study on the relationships between organizational learning and organizational performance and measured the impact of four strategies of learning organizations on organizational performance of employees in private banks in Pakistan. The researchers collected data on four of seven strategies of the $D L O Q$ - continuous learning, team learning, empowerment, and leadership_ using 28 items. The study revealed moderate to strong positive relationships among the four subscales of the $D L O Q$ with organizational performance, ranging from .36 (organizational performance and leadership) to .87 (continuous learning and leadership). Based on the correlations, the researchers developed a regression model. The results revealed that, combined, the four subscales of the $D L O Q$ significantly predicted organizational performance, $F(50,3)=50.3, p=.000$. The results showed that continuous learning and empowerment were the most significant factors that increased organizational performance, whereas leadership and team learning did not show significant effects.

A similar study was conducted by Akhtar, Arif, Erum, and Naveed [23] in higher education in Pakistan. The authors investigated the impact of organizational learning on organizational performance of higher education institutions of Pakistan. The researchers adopted the DLOQ [26], [29] and, using a non-probability purposive sampling technique, distributed the questionnaire to 150 employees of the public and private higher education institutes. The results revealed that inquiry and dialogue, and system connections were highly correlated to organizational performance; however, the five other dimensions were found to be insignificant predictors of organizational performance.

Usman, Danish, Waheed, and Tayyeb [1] conducted a study investigating the significance of moderating effects of employees' education on the relationship between feedback, job role innovation, and organizational learning culture in Pakistan. The researchers used the $D L O Q$ [26], [29] to measure organizational learning culture of the university employees. Using a stratified sampling technique, the researchers selected 210 participants including lecturers, assistant professors, associate professors, and professors. The moderating effect of employees' education on the relationship between job role and organizational learning culture was found to be significant as the beta value reduced from $B=0.457$ to $B=0.160$ with a change in significance level from 0.00 to 0.29 .

Malik, Danish, and Usman [17] conducted a study measuring the impact of motivation to learn and job attitudes on organizational learning culture of a public service organization in Pakistan. The researcher used the $D L O Q$ to measure the learning culture of the public service organization [26], [29]. The data were collected from 119 employees. Interestingly, the results showed that organizational learning culture was significantly and positively related to satisfaction, organizational commitment, and job involvement but not with motivation to learn.

These studies provide valid evidence of the impact of a learning culture on organizational performance of employees working outside of school contexts. Other studies provide partial evidence of the significance of individual dimensions and their effects on student achievement - the focus of our study. Marks and Louis [10], for example, conducted a study to investigate teacher empowerment effects on student achievement. The researchers selected 24 elementary, middle, and high schools-eight schools at each grade level. Data sources included teacher surveys, ratings of pedagogical quality, assessments of student academic performance, and case studies based on interviews and observations. The results suggested that empowerment appeared to be an important but not sufficient condition of obtaining real changes in teachers' ways of working and their instructional practices. Also the effects of empowerment on classroom practice varied depending on the domain in which teacher influence is focused. Further, teacher empowerment affected pedagogical quality and student academic performance indirectly through school organization for instruction.

Research into school effectiveness is considered a starting point for examining the impact of educational leadership on student outcomes [3]. The results of this research suggest that effective educational leadership is an important characteristic of effective schools. According to these findings, principals should have high expectations of teachers and student achievement, supervise teachers, coordinate the curriculum, emphasize basic skills, and monitor student progress. Hallinger and Heck [21] examined the empirical literature on principal effects that emerged during a period between 1980 and 1995. They reviewed 40 studies and found that leaders' practices can affects school outcomes.

These whole system strategies provide mixed results in terms of their impact on student achievement. So far, the researchers have not been able to find any study that employed the $D L O Q$ to measure the effect of organizational learning culture on student achievement. It is significant to know whether the schools that differ in their effectiveness or school performance also differ in their learning culture. This study will fill this gap by measuring the learning culture of high and low performing high schools in Pakistan. 


\section{Methodology}

The purpose of this research was to compare the learning culture of high and low performing boys and girls high schools in Pakistan. Data collection was accomplished using the adapted version of the Dimensions of a Learning Organization Questionnaire [26], [27]. Data were analyzed using SPSS Version 20.0.

\subsection{Research questions}

The study involved the following research questions:

1. To what extent do public high schools in Pakistan exhibit the dimensions of a learning culture?

2. Do boys and girls high schools in Pakistan differ on the dimensions of a learning culture?

3. Do high and low performing high schools in Pakistan differ in dimensions of a learning culture?

4. Do high and low performing high schools for boys and girls in Pakistan differ in dimensions of a learning culture?

\subsection{Sample}

All the headmasters and headmistresses of boys and girls high schools $(\mathrm{N}=174)$ in one district of Lahore were sampled for the current study. Among them, 10 high schools did not have regular administrators. The final sample size, therefore, was 164 schools. The researchers received 164 questionnaires (66 from the headmasters and 98 from the headmistresses) in complete form. Due to multiple contacts with the respondents, the response rate was 100 percent.

\subsection{Instrumentation}

The $D L O Q$ was adapted to the Pakistani school context by Akram and Watkins to measure seven dimensions of a learning culture and key performance indicators. Item stems were changed to say "in my school," vs "in my organization and language changed where appropriate to reflect the school context while maintaining the integrity of the construct. Overall, very few changes were made to the items beyond the initial stem. The $D L O Q$ has been extensively validated [2] and has proved highly reliable in multiple forms, languages and contexts.

\subsection{Data collection}

The $D L O Q$ was mailed to the participants. One of the researchers (third author) collected the mailing addresses of all the headmasters and headmistresses working within the vicinity of Lahore district. He mailed questionnaires to the school administrators at their respective school addresses. The instrument was administered during the month of October 2011. The participants showed their interest in the instrument, completed, and returned the questionnaire within a three-week time period.

\subsection{Data analysis}

First, data were entered into an Excel spreadsheet and then uploaded into SPSS. Combining the items under each dimension, variables were codified. The instrument demonstrated a high level of reliability with Cronbach alpha coefficients as high as .94.The reliability of each dimension ranged from .84 to .94 . Further analyses were conducted according to the following research questions.

\section{Findings}

Research Question 1. To what extent do public high schools in Pakistan exhibit the dimensions of a learning culture?

Table 1 gives descriptive statistics to determine the extent to which the participating schools exhibit dimensions of a learning organization.

\section{Table 1. Descriptive Statistics}

\begin{tabular}{|l|l|l|l|l|l|}
\hline Dimensions & $\mathrm{N}$ & Min & Max & Mean & SD \\
\hline $\begin{array}{l}\text { Continuous } \\
\text { Learning }\end{array}$ & 164 & 1.29 & 6.00 & 4.28 & .87 \\
\hline $\begin{array}{l}\text { Dialogue and } \\
\text { Inquiry }\end{array}$ & 164 & 1.50 & 6.00 & 4.45 & .82 \\
\hline $\begin{array}{l}\text { Collaboration } \\
\text { Team Learning }\end{array}$ & 164 & 2.17 & 6.00 & 4.73 & .89 \\
\hline $\begin{array}{l}\text { Embedded } \\
\text { Learning }\end{array}$ & 164 & 2.33 & 6.00 & 4.52 & .91 \\
\hline $\begin{array}{l}\text { Empower } \\
\text { people }\end{array}$ & 164 & 2.17 & 6.00 & 4.68 & .83 \\
\hline $\begin{array}{l}\text { System } \\
\text { Connection }\end{array}$ & 164 & 2.17 & 6.00 & 4.72 & .84 \\
\hline $\begin{array}{l}\text { Strategic } \\
\text { Leadership }\end{array}$ & 164 & 1.67 & 6.00 & 4.80 & .86 \\
\hline $\begin{array}{l}\text { Financial } \\
\text { Performance }\end{array}$ & 164 & 1.83 & 6.00 & 4.30 & .87 \\
\hline $\begin{array}{l}\text { Knowledge } \\
\text { Performance }\end{array}$ & 164 & 2.83 & 6.00 & 4.85 & .74 \\
\hline
\end{tabular}

The minimum value of the responses against the DLOQ dimensions ranged from 1.29 (Continuous Learning) to 2.33 (Embedded Learning). The Maximum value of the responses remained 6.00. The mean value of the DLOQ dimensions ranged from 4.28 (Continuous Learning) to 4.85 (Strategic Leadership). We conclude that Pakistani schools exhibit an above average learning culture (overall mean of 4.597 on the seven dimensions of a learning 
culture) and above average on the two performance dimensions (overall mean of 4.575).

Research Question 2. Do boys and girls high schools in Pakistan differ on the dimensions of a learning culture?

The researchers hypothesized that boys and girls high schools would differ on their score on the dimensions of the learning culture. The descriptive analysis showed that the mean score of girls' schools (from 4.39 to 5.03) was higher than that of boys' (3.99 to 4.59). The t-test for independent samples was conducted to see whether boys and girls schools differed on learning culture measures. Headmistresses reported significantly higher scores in 8 out of 9 dimensions of a learning culture than headmasters. Only in one dimension, Financial Performance, was the difference between boys and girls high schools non-significant, $t(162)=-1.71$, . .08. The summary of the results is in Table 2.

Table 2. T-test for Independent Samples

\begin{tabular}{|c|c|c|c|c|c|c|}
\hline & Gender & Mean & $f$ & $\mathrm{t}$ & $\mathrm{df}$ & Sig. \\
\hline \multirow[t]{2}{*}{ CL } & Boys & 3.99 & \multirow[t]{2}{*}{0.03} & \multirow[t]{2}{*}{-3.60} & \multirow[t]{2}{*}{162} & \multirow[t]{2}{*}{$.000 *$} \\
\hline & Girls & 4.47 & & & & \\
\hline \multirow[t]{2}{*}{ DI } & Boys & 4.13 & \multirow[t]{2}{*}{4.53} & \multirow[t]{2}{*}{-4.36} & \multirow[t]{2}{*}{162} & \multirow[t]{2}{*}{$.000 *$} \\
\hline & Girls & 4.67 & & & & \\
\hline \multirow[t]{2}{*}{$\mathrm{CT}$} & Boys & 4.41 & \multirow[t]{2}{*}{15.14} & \multirow[t]{2}{*}{-3.91} & \multirow[t]{2}{*}{162} & \multirow[t]{2}{*}{$.000 *$} \\
\hline & Girls & 4.94 & & & & \\
\hline \multirow[t]{2}{*}{ EL } & Boys & 4.28 & \multirow[t]{2}{*}{1.77} & \multirow[t]{2}{*}{-2.81} & \multirow[t]{2}{*}{162} & \multirow[t]{2}{*}{$.005 *$} \\
\hline & Girls & 4.68 & & & & \\
\hline \multirow[t]{2}{*}{ EP } & Boys & 4.40 & \multirow[t]{2}{*}{11.82} & \multirow[t]{2}{*}{-3.66} & \multirow[t]{2}{*}{162} & \multirow[t]{2}{*}{$.000 *$} \\
\hline & Girls & 4.87 & & & & \\
\hline \multirow[t]{2}{*}{ SC } & Boys & 4.52 & \multirow[t]{2}{*}{0.56} & \multirow[t]{2}{*}{-2.52} & \multirow[t]{2}{*}{162} & \multirow[t]{2}{*}{$.013 *$} \\
\hline & Girls & 4.86 & & & & \\
\hline \multirow[t]{2}{*}{ SL } & Boys & 4.48 & \multirow[t]{2}{*}{2.54} & \multirow[t]{2}{*}{-4.08} & \multirow[t]{2}{*}{162} & \multirow[t]{2}{*}{$.000 *$} \\
\hline & girls & 5.02 & & & & \\
\hline \multirow[t]{2}{*}{ FP } & Boys & 4.16 & 1.53 & -1.71 & 162 & .089 \\
\hline & Girls & 4.39 & & & & \\
\hline $\mathrm{KP}$ & Boys & 4.59 & 1.33 & -3.86 & 162 & $.000 *$ \\
\hline & Girls & 5.03 & & & & \\
\hline
\end{tabular}

*Differences were significant (2-tailed).

Research Question 3. Do high and low performing high schools in Pakistan differ on dimensions of a learning culture?

The researchers hypothesized that high and low performing high schools in Pakistan would differ in their score on the dimensions of the learning culture. The summary of the results is presented in Table 3.
Table 3. T-test for independent Samples

\begin{tabular}{|c|c|c|c|c|c|c|}
\hline & Performing & Mean & $\mathrm{f}$ & $\mathrm{t}$ & $\mathrm{df}$ & Sig. \\
\hline \multirow[t]{2}{*}{$\mathrm{CL}$} & Low & 4.17 & \multirow[t]{2}{*}{.16} & \multirow{2}{*}{-.12} & \multirow[t]{2}{*}{58} & \multirow[t]{2}{*}{.900} \\
\hline & High & 4.20 & & & & \\
\hline \multirow[t]{2}{*}{ DI } & low & 4.31 & \multirow[t]{2}{*}{1.54} & \multirow[t]{2}{*}{-.90} & \multirow[t]{2}{*}{58} & \multirow[t]{2}{*}{.370} \\
\hline & High & 4.51 & & & & \\
\hline \multirow[t]{2}{*}{$\mathrm{CT}$} & Low & 4.66 & \multirow[t]{2}{*}{.23} & \multirow[t]{2}{*}{-.61} & \multirow[t]{2}{*}{58} & \multirow[t]{2}{*}{.539} \\
\hline & High & 4.79 & & & & \\
\hline \multirow[t]{2}{*}{$\overline{E L}$} & Low & 4.37 & \multirow[t]{2}{*}{.00} & \multirow[t]{2}{*}{-.45} & \multirow[t]{2}{*}{58} & \multirow[t]{2}{*}{.652} \\
\hline & High & 4.47 & & & & \\
\hline \multirow[t]{2}{*}{ EP } & Low & 4.53 & \multirow[t]{2}{*}{.45} & \multirow[t]{2}{*}{-.92} & \multirow[t]{2}{*}{58} & \multirow[t]{2}{*}{.358} \\
\hline & High & 4.72 & & & & \\
\hline \multirow[t]{2}{*}{$\mathrm{SC}$} & Low & 4.65 & \multirow[t]{2}{*}{.06} & \multirow[t]{2}{*}{-.41} & \multirow[t]{2}{*}{58} & \multirow[t]{2}{*}{.678} \\
\hline & High & 4.74 & & & & \\
\hline \multirow[t]{2}{*}{$\mathrm{SL}$} & Low & 4.57 & \multirow[t]{2}{*}{.095} & \multirow[t]{2}{*}{-2.01} & \multirow[b]{2}{*}{58} & \multirow[t]{2}{*}{$.048^{*}$} \\
\hline & High & 4.96 & & & & \\
\hline \multirow[t]{2}{*}{ FP } & Low & 4.03 & 2.37 & -1.21 & 58 & .230 \\
\hline & High & 4.30 & & & & \\
\hline KP & Low & 4.52 & .17 & -2.69 & 58 & $.009 *$ \\
\hline & High & 4.98 & & & & \\
\hline
\end{tabular}

On the basis of the schools' overall student achievement on the BISE Lahore exams in 2011, the researchers selected 30 high and 30 low performing high schools. The t-test for independent samples revealed that high performing schools demonstrated significantly higher mean scores $(\mathrm{M}=4.96, \mathrm{SD}=.66)$ than the low performing high schools $(\mathrm{M}=4.57$, $\mathrm{SD}=.82$ ) on Strategic Leadership, $t(58)=-2.017$, $p=.048$, followed by Knowledge Performance $(\mathrm{M}=4.98, \quad \mathrm{SD}=.62)$, as compared to the low performing high schools $(\mathrm{M}=4.52, \mathrm{SD}=.69), t(58)=-$ $2.69, p=.009$. However, no statistically significant differences were found between high and low performing high schools on the other seven dimensions of the learning culture.

Research Question 4. Do high and low performing high schools for boys and girls differ on dimensions of a learning culture?

The researchers hypothesized that the boys' high schools would differ on their score on the dimensions of a learning culture. On the basis of the board results of each school, the researchers selected 30 high and 30 low performing boys' high schools. The t-test for independent samples was conducted to see whether the boys' schools significantly differed on the dimensions of the learning culture. The results revealed no statistically significant differences between the scores of the high and low performing boys' high schools on the DLOQ dimensions.

The researchers also hypothesized that the girls' high schools would differ on their score on the dimensions of the learning culture. On the basis of the board results of each school, the researchers selected 30 high and 30 low performing girls' high schools. The t-test for independent samples was 
conducted to see whether the girls' schools significantly differed on the dimensions of the learning culture. No statistically significant differences were found between the scores of the low and high performing girls' high schools on the $D L O Q$ dimensions.

\section{Discussion}

The purpose of this study was to measure the learning culture of high and low performing high schools in Pakistan. Within the Watkins and Marsick [27] theoretical framework, the Dimensions of Learning Organization Questionnaire (DLOQ) was employed as a diagnostic tool to measure the learning culture of 164 high schools in one district of the province of Lahore. High and low performing high schools showed significant difference on the dimensions of strategic leadership for learning and knowledge performance. The results revealed that headmistresses rated their schools higher in strategic leadership for learning and knowledge performance than the headmasters. Significant inter-correlations among all dimensions of the $D L O Q$ were found as in other studies [2]. Student achievement correlated with only two of the dimensions i.e. Strategic Leadership for Learning and Knowledge Performance.

The study involved a couple of limitations. First, the sample size was small. And at the same time, collecting data from each headmaster and headmistress of the district is a difficult and time consuming task. Further study with a larger sample size, including teachers, may provide more interesting and different results. A second limitation is related to the sample which was drawn using a nonrandom technique. Due to the nonrandomization, the researchers cannot claim that results found significant are completely due to the dimensions measured by the $D L O Q$ and not by chance. A randomized sample, even a stratified random sample would provide more reliable results. On the basis of the results of this study, further studies can be conducted investigating the impact of a learning culture on student achievement through conducting regression analysis.

One implication is related to the school's overall results in the board examinations. It is needless to say that the schools differ in their size, number of teachers and experience. On the basis of such differences, the researchers believe the schools' overall results can be affected by various extraneous variables. Private tuition is another strong indicator that helps students increase achievement to a significant level. However, the overall results of the study are nevertheless encouraging.

This is the first study which provides evidence of differences of a learning culture in high and low performing high schools in Pakistan. If student achievement can be influenced by strategic leadership for learning, then training in this dimension may help low performing high schools attain higher student achievement in the board exams. Special training sessions from the provincial and district education offices would provide ample opportunities to the administrators to transform their schools into learning communities. In addition, given the significant correlation between student achievement and knowledge performance of the organization, the administrators can focus on (a) adopting innovations such as IT resources, and (b) creating new learning programs such as effective leadership practices to increase their and their subordinates' leadership capacities. With further study, we may have evidence that would allow us to laser focus professional development to those areas most likely to influence student achievement.

\section{Acknowledgements}

The authors wish to thank the headmasters and headmistresses of the participating schools in District Lahore, Pakistan.

\section{References}

[1] A. Usman, R.Q. Danish, N. Waheed, and U. Tayyeb, "Moderating effect of employees' education on relationship between feedback, job role innovation and organizational learning culture", African Journal of Business Management, 5(5), 2011, pp. 1684-1690.

[2] B. Yang, K.E, Watkins, and V. J. Marsick, "The Construct of the Learning Organization; Dimensions, measurement, and validation", Human Resources Development Quarterly, 15(1), 2004, pp. 31-56.

[3] Brookover, W.B., C. Beady, P. Flood, J. Schweitzer, and J. Wisenbaker, School social systems and student achievement. Schools can make a difference. Praeger, New York, 1979.

[4] Bryman, A., and E. Bell, Business Research Methods. Oxford University Press, Oxford, 2003.

[5] C. Giles, and A. Hargreaves, "The sustainability of innovative schools as learning organizations and professional learning communities during standardized reform", Educational Administration Quarterly, 42, 2006, pp. 124-156.

[6] C. Schechter, "Organizational learning mechanisms: The meaning, measure, and implications for school improvement", Educational Administration Quarterly, 44(2), 2008, pp. 155-186.

[7] D. R. Wood, "Professional learning communities: Teachers, knowledge, and knowing", Theory into Practice, 46(4), 2007, pp. 281-290.

[8] G. Doolittle, M. Sudeck, and P. Rattigan, "Creating professional learning communities: The work of 
professional development schools", Theory into Practice, 47, 2008, pp. 303-310.

[9] Gamoran, A., A. Porter, C., and T. Gahng, Teacher empowerment: A policy in search of theory and evidence. In W. J. Fowler, B. Levin, \& H. J. Walberg (Eds.), Organizational influences on educational productivity, 5, JAI Press. Greenwich, CT, pp. 175-193, 1996.

[10] H. M. Marks, and K.S. Louis, "Does teacher empowerment affect the classroom? The implications of teacher empowerment for instructional practice and student academic performance", Educational Evaluation and Policy Analysis, 19(3), 1997, pp. 245-275.

[11] Hargreaves, A., Teaching in the knowledge society, Teachers College Press, New York, 2003.

[12] Howitt, D., and D. Cramer, A guide to computing statistics with SPSS for windows, Prentice-Hall, London, 2001.

[13] J.H. Chrispeels, P.H. Burke, P. Johnson, and A.J. Daly, "Aligning mental models of district and school leadership teams for reform coherence", Education and Urban Society, 40(6), 2008, pp. 730-750.

[14] K. Leithwood, and D. Jantzi, "Linking leadership to student learning: The contributions of leader efficacy", Educational Administration Quarterly, 44(4), 2008, pp. 496-528.

[15] K.E. Watkins, J. Milton, and D. Kurz, "Diagnosing the Learning Culture in Public Health Agencies", International Journal of Continuing Education and Lifelong Learning, 2(1), 2009, pp. 65-81.

[16] L. Servage, "Critical and transformative practices in professional learning communities", Teacher Education Quarterly, 35(1), 2008, pp. 63-77.

[17] M. E. Malik, R.Q. Danish, and A. Usman, "Impact of motivation to learn and job attitudes on organizational learning culture $\mathrm{n}$ a public service organization of Pakistan", African Journal of Business Management, 5(3), 2011, pp. 844-854.

[18] M. Imran, S. H. M. Rizvi, and B. Ali, "Impact of organizational learning on organizational performance", International Journal of Academic Research, 3(4), 2001, pp. 424-427.

[19] Nunnally, J.C., Psychometric theory, McGraw-Hill, New York, 1978.

[20] P. Graham, "Improving teacher effectiveness through structured collaboration: A case study of a professional learning community", Middle Level Education Online, 31(21), 2007, pp. 1-32.

[21] P. Hallinger, and R.H. Heck, "Exploring the principals' contribution to school effectiveness: 19801995", School Effectiveness and School Improvement, 9(2), 1998, pp. 157-191.
[22] R. DuFour, "What is a professional learning community?", Educational Leadership, 2004, pp. 1-6.

[23] S. Akhtar, A. Arif, E. Rubi, and S. Naveed, "Impact of organizational learning on organizational performance", International Journal of Academic Research, 3(5), 2011, pp. 327-331.

[24] S.M. Printy, "Leadership for teacher learning: A community of practice perspective", Educational Administration Quarterly, 44(2), 2008, pp. 187-226.

[25] T.H. Levine, and A.S. Marcus, "Closing the achievement gap through teacher collaboration: Facilitation multiple trajectories of teacher learning", Journal of Advanced Academics, 19(1), 2007, pp. 116-138.

[26] V.J. Marsick, and K.E. Watkins, "Demonstrating the value of an organization's learning culture: The dimensions of the learning organization questionnaire", Advances in Developing Human Resources, 5(2), 2003, pp. 132-151.

[27] Watkins, K. E., \& V.J. Marsick, Dimensions of the learning organization. Partners for the Learning Organization, Warwick, RI: 1997.

[28] Watkins, K. E., \& V.J. Marsick, In action: Creating the learning organization. American Society for Training and Development, Alexandria, VA: 1996.

[29] Watkins, K. E., and V.J. Marsick, Sculpting the learning organization. Jossey-Bass, San Francisco, 1993. 